\title{
Penerapan Multimedia dalam Pembelajaran Bahasa Inggris pada Guru Sekolah Tingkat Dasar dan Menengah
}

\author{
Ahmad Thoyyib Shofi ${ }^{1}$, Eva Nur Mazidah ${ }^{2}$, Fauziyatun Ni' mah $^{3}$ \\ ${ }_{1,2,3}$ Prodi Pendidikan Bahasa Inggris, STKIP Qomaruddin Gresik \\ 1'thoyyib.shofi@ stkipqomaruddin.ac.id, ${ }^{2}$ evamazidah@gmail.com, ${ }^{3}$ zyazhie40@gmail.com
}

\begin{abstract}
Learning is a process with regard to the learners, teachers, and materials in the studying circumstance. Hence, learning could be done anytime and anywhere. In this case, teaching and learning process should use the media. Educators must be prepared with the development of media technology. Teaching language which is assisted by television, laptop, film, projector, video, smartphone and tablet usually called multimedia assisted language learning (MALL). Regarding the language teaching and learning process, some people realize that the traditional teaching model is no longer effective to support the student's need. In teaching English, a teacher should be able to use multimedia in teaching and learning process so that they can make a joyful and effective learning rather than teaching with the traditional ways that are sometimes made the students bored. The use of the traditional model is normally caused by the lack of teachers in using modern technology. The problem identification shows that English teachers at the primary and secondary school in Bungah regency still use traditional English teaching model. Therefore, we need to conduct a workshop on applying multimedia assisted language learning in order to teach English teacher how to produce the effective, interesting and joyful teaching.
\end{abstract}

Keywords: Applying, Multimedia, English learning

\begin{abstract}
ABSTRAK
Belajar merupakan suatu proses keterkaitan antara peserta didik, pendidikan, dan materi yang diajarkan dalam lingkungan belajar. Oleh karena itu, belajar dapat terjadi kapan saja dan di mana saja. Dalam hal ini, pendidik dituntut untuk menggunakan media yang ada. Selain itu, pendidik juga harus siap dengan perubahan media yang sesuai dengan perubahan teknologi. Pengajaran yang menggunakan media seperti televisi, laptop, film, proyektor, video, ponsel pintar, dan tablet biasanya disebut dengan pembelajaran berbasis multimedia. Berkaitan dengan pembelajaran bahasa dewasa ini, setiap orang semakin menyadari bahwa pengajaran bahasa secara tradisional tidak lagi efektif untuk menunjang kebutuhan peserta didik. Begitu juga dengan pembelajaran Bahasa Inggris, guru juga dituntut dapat menggunakan multimedia dalam proses pembelajaran demi mewujudkan pembelajaran yang menyenangkan dan efektif daripada menggunakan media tradisional yang diasumsikan cepat membosankan. Tanpa dipungkiri bahwa pembelajaran tradisional yang diterapkan oleh pendidik pada pembelajaran Bahasa Inggris merupakan kurangnya penguasaan iptek oleh guru. Berdasarkan hasil identifikasi masalah, didapatkan bahwa guru-guru Bahasa Inggris tingkat dasar dan menengah di Kecamatan Bungah, Gresik masih menggunakan media tradisional sehingga perlu diberikan sosialisasi dan pelatihan penerapan multimedia dalam pembelajaran Bahasa Inggris agar tercipta suatu proses berlajar yang menarik, efektif, dan menyenangkan.
\end{abstract}

Kata kunci: Penerapan, Multimedia, Pembelajaran Bahasa Inggris

\section{PENDAHULUAN}

Belajar merupakan suatu proses keterkaitan antara peserta didik, pendidikan, dan materi yang diajarkan dalam lingkungan belajar (Aqib, 2008). Adanya interaksi antara sesorang dan lingkungan adalah sebuah proses belajar. Oleh karena itu, belajar dapat terjadi kapan saja dan di mana saja. Salah satu bukti bahwa seseorang telah berhasil belajar adalah adanya perubahan tingkah laku pada diri seseorang yang disebabkan oleh terjadinya perubahan pada tingkat pengetahuan, keterampilan, dan sikap di mana pun dan kapan pun.

Dalam hal ini, pendidik dituntut untuk menggunakan alat-alat yang ada. Selain itu, pendidik juga harus siap dengan perubahan alat sesuai dengan perubahan teknologi yang mengikuti perubahan zaman. Perkembangan teknologi berdampak pada perkembangan model belajarmengajar. Dalam proses pembelajaran, pendidik dapat menggunakan alat seperti televisi, laptop, 
film, proyektor, video, ponsel pintar, dan tablet. Pengajaran yang menggunakan alat-alat tersebut biasanya disebut dengan pembelajaran berbasis multimedia. Dalam teknologi, alat-alat tersebut disebut dengan hardware dan software (Asyrofi, 2010). Dalam proses pembelajaran, guru dituntut agar menjadikan proses pembelajaran berlangsung kondusif. Salah satu caranya adalah dengan menggunakan metode yang baik dengan didukung oleh penggunaan media yang baik pula. Dalam pemilihan media pembelajaran dibutuhkan media pembelajaran yang dapat membantu pendidik dalam penyampaikan pesan kepada siswa agar pesan tersebut tersampaikan dengan jelas dan mudah dipahami oleh peserta didik.

Perkembangan ilmu pengetahuan dan teknologi yang begitu pesat, terutama dalam hal perkembangan teknologi komunikasi, media pembelajaran yang digunakan oleh guru saat ini bukan hanya terpaku pada media pembelajaran konvensional yang berupa papan tulis, gambar, dan poster. Adanya teknologi komunikasi yang berupa multimedia seperti laptop, video, MP3, ponsel pintar/tablet, film pendek, dan lain sebagainya juga dapat dimanfaatkan sebagai media pembelajaran. Dengan menggunakan multimedia modern, peserta didik diasusmsikan akan lebih senang dan terhindar dari proses belajar yang membosankan. Salah satu bukti positif keberhasilan proses pembelajaran adalah dapat menarik perhatian peserta didik. Dengan menggunakan multimedia, pembelajaran akan lebih efektif.

Berkaitan dengan pembelajaran bahasa dewasa ini, setiap orang semakin menyadari bahwa pengajaran bahasa secara tradisional tidak lagi efektif untuk menunjang kebutuhan peserta didik (Kusnandar, 2007). Untuk itu, pendidik berusaha menemukan pembelajaran modern dengan memanfaatkan kecanggihan multimedia. Begitu juga dengan pembelajaran Bahasa Inggris, pendidik juga dapat menggunakan multimedia dalam pendidikan demi mewujudkan proses pembelajaran yang menyenangkan dan efektif. Namun, pada jenjang pendidikan level dasar dan menengah, pendidik Bahasa Inggris pada umumnya masih menggunakan media tradisional, yakni menggunakan papan tulis atau gambar.

\section{METODE PELAKSANAAN}

Metode pelaksanaan kegiatan yang akan digunakan adalah sosialisasi dan pelatihan penerapan multimedia. Adapun tahapan pelaksanaan kegiatan ini sebagai berikut.

\subsection{Sosialisasi Penerapan Multimedia dalam Pembelajaran Bahasa Inggris}

Kegiatan dilaksanakan melalui pemaparan dan demonstrasi. Para penyaji memperkenalkan kepada peserta pelatihan bagaimana cara memilih media yang cocok untuk digunakan dalam pembelajaran, baik pembelajaran vocabulary, speaking, dan penggunaan game.

\subsection{Pelatihan Penerapan Multimedia dalam Pembelajaran Bahasa Inggris}

Setelah peserta mendapatkan pemaparan dan demostrari, langkah selanjutnya yaitu pelatihan praktik pengajaran menggunakan multimedia. Peserta praktik dibagi menjadi enam kelompok. Masing-masing kelompok mendemonstrasikan pengajaran berbasis multimedia. Pada praktik ini, peserta terlihat sangat antusias, praktik terasa menyenangkan, dan peserta praktik terlihat senang dengan demonstrasinya.

\subsection{Memberikan Umpan Balik terhadap Pelatihan}

Setelah sosialisasi dan pelatihan pengajaran Bahasa Inggris berbasis multimedia berakhir, tim pengabdian kepada masyarakat memberikan angket kepada peserta sebagai alat untuk mengukur keberhasilan program. Poin pertanyaan pada angket dibagi menjadi tiga, yaitu mengenai pemateri, materi, dan sarana/prasarana. Berdasarkan jawaban dari angket yang telah dirangkum, umpan balik yang diberikan kepada peserta pelatihan adalah follow up yang bersifat konsultatif. Peserta dilayani dengan menjawab keluhan-keluhan mengenai pembelajaran Bahasa Inggris berbasis multimedia. 


\subsection{Laporan Hasil Pengabdian kepada Masyarakat}

Laporan hasil pengabdian kepada masyarakat dibuat setelah pelaksanaan program pengabdian kepada masyarakat usai. Laporan ini dibuat berdasarkan kondisi sebenarnya selama pelatihan. Selanjutnya, luaran dari kegiatan ini adalah submit jurnal kegiatan pengabdian ini kepada pengelola e-jurnal yang ber-ISSN.

\section{HASIL DAN PEMBAHASAN}

Hasil pengabdian kepada masyarakat yang dilaksanakan dengan cara tatap muka dan praktik pengajaran menggunakan multimedia berjalan dengan baik dan lancar. Pertemuan tatap muka dilakukan dengan metode ceramah dan demonstrasi, dilanjutkan dengan praktik/latihan mengajar dengan menggunakan multimedia, mulai dari pemilihan materi, pemilihan multimedia, dan pemaduan antara keduanya dalam pembelajaran. Kegiatan ini dilaksanakan dalam sehari, yaitu pada Rabu, 19 Februari 2018 mulai pukul 08.00-13.30 WIB. Peserta kegiatan berjumlah 26 orang guru tingkat dasar dan menengah. Sebagian besar peserta pelatihan ini adalah guru sekolah tingkat dasar yang bukan lulusan/sarjana Bahasa Inggris.

Pelaksanaan kegiatan pengabdian masyarakat ini dilakukan oleh lima orang tim pengabdi dengan pokok bahasan yang disampaikan mengenai

1) metode pembelajaran vocabulary dengan multisensory technical kepada anak usia dini;

2) metode pembelajaran joyful learning;

3) pengajaran menggunakan multimedia dalam pembelajaran Bahasa Inggris dengan media video dan powerpoint;

4) latihan pembelajaran dengan multimedia; serta

5) evaluasi hasil pembelajaran yang telah dilaksanakan.

Kegiatan yang diawali dengan ceramah dan demostrasi ini kemudian dilanjutkan dengan latihan. Dari kegiatan latihan, tampak bahwa guru memang belum menguasai cara pembelajaran berbasis multimedia. Banyak alasan yang disampaikan oleh guru-guru terkait hambatan dalam pembelajaran menggunakan multimedia. Para guru mengeluhkan kurangnya pengalaman tentang metode pengajaran Bahasa Inggris karena latar belakang pendidikan mereka bukan sarjana/lulusan Pendidikan Bahasa Inggris, serta kurangnya penguasaan TIK dalam proses pembelajaran, khususnya pembelajaran berbasis multimedia.

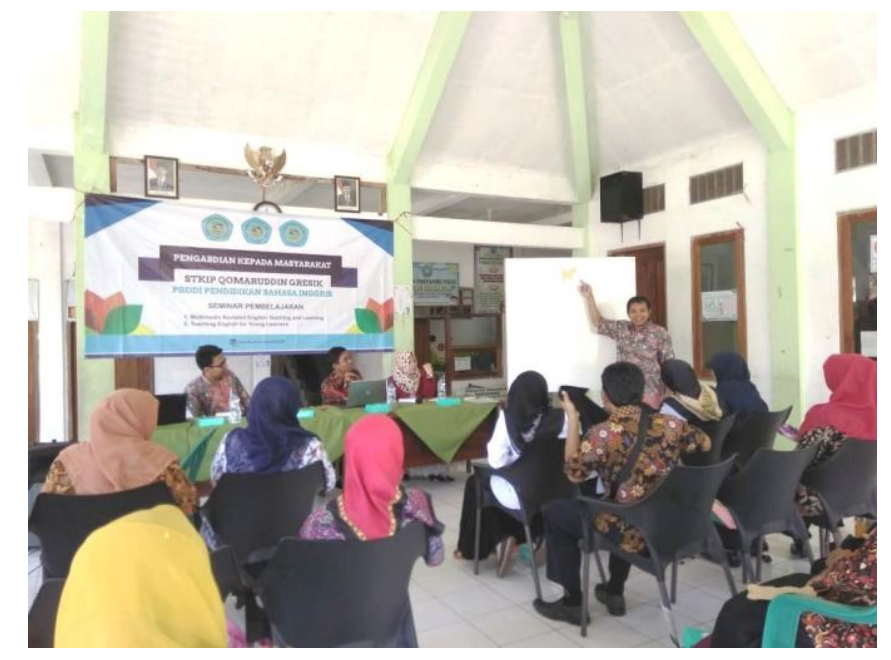

Gambar 1. Demonstrasi

Sesi terakhir dalam acara ini adalah tanya jawab. Berbagai pertanyaan diajukan dengan antusias.

Secara garis besar, inti pertanyaan para peserta terkait

1) metode pengajaran yang baik untuk anak usia dini;

2) teknik mengajarkan vocabulary dan pronunciation kepada anak usia dini;

3) langkah-langkah pengajaran berbasis multimedia; 
4) pemilihan video untuk pembelajaran;

5) pembuatan game powerpoint untuk pembelajaran; dan

6) situs web untuk mengunduh game power point.

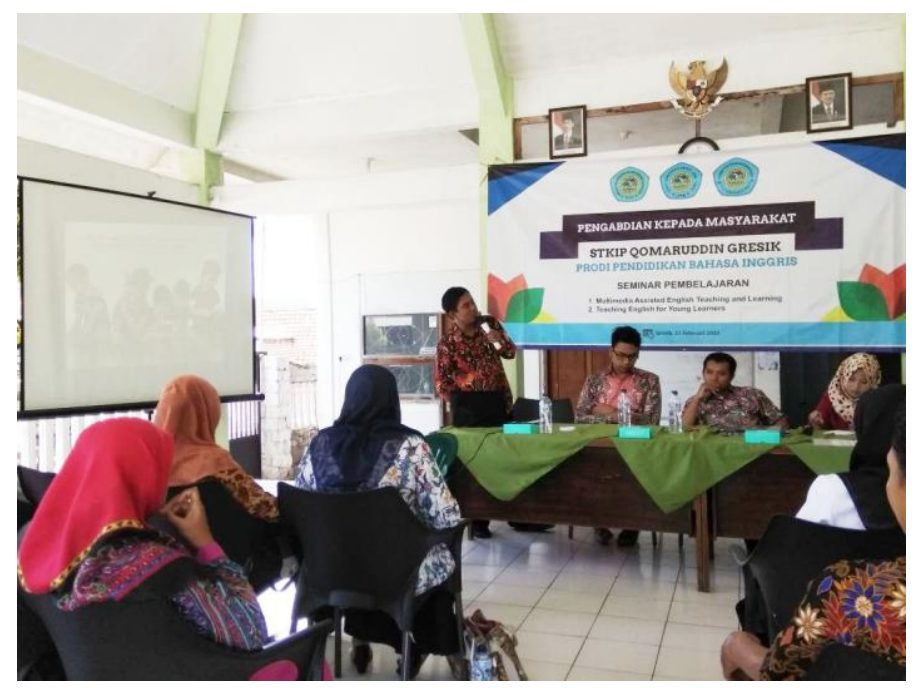

Gambar 2. Pembelajaran dengan Multimedia

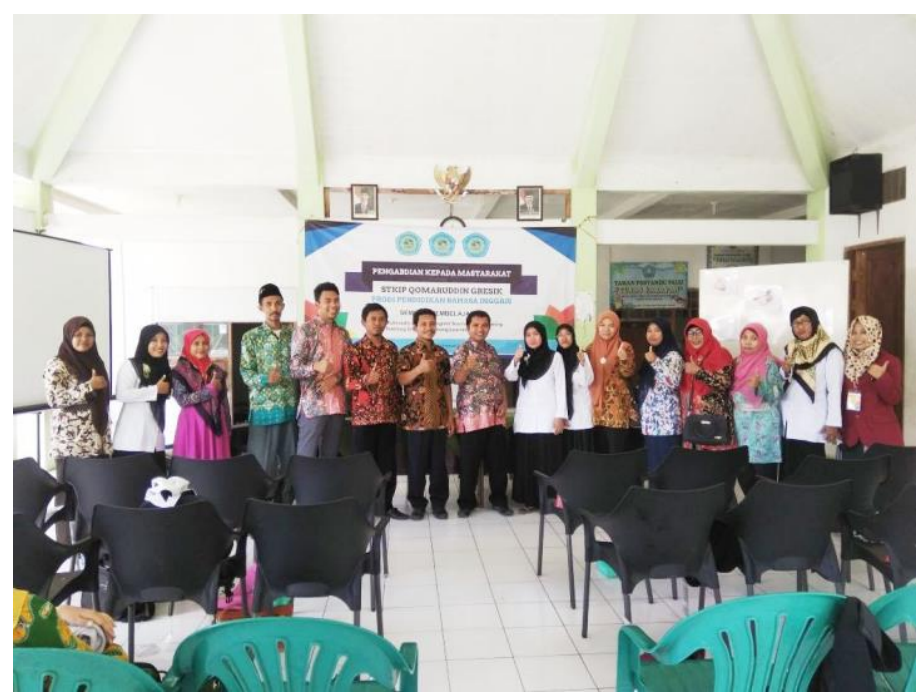

Gambar 3. Foto dengan Sebagian Peserta Pelatihan

Hasil pelatihan ini akan bermanfaat bagi sekolah. Proses pembelajaran dengan dibantu oleh multimedia akan menambah kualitas dalam pembelajaran karena pembelajaran terasa lebih menarik dan menyenangkan. Selain itu, adanya pelatihan ini akan berimplikasi pada peningkatan keterampilan guru, baik dalam pengajaran maupun dalam pembuatan perangkat pembelajaran.

\section{KESIMPULAN}

Kegiatan ini sangat membantu guru dalam meningkatkan pengetahuan dan kemampuan dalam mengajar Bahasa Inggris di tingkat anak-anak dengan memanfaatkan multimedia. Berdasarkan saran-saan yang diterima, acara semacam ini diharapkan bisa dilakukan secara rutin untuk memperkaya pengetahuan para guru untuk memanfaatkan multimedia dan membuat suasana pembelajaran di kelas menjadi lebih efektif dan menyenangkan. 


\section{UCAPAN TERIMA KASIH}

Kegiatan pengabdian kepada masyarakat dengan judul Penerapan Multimedia dalam Pembelajaran Bahasa Inggris pada Guru Sekolah Tingkat Dasar dan Menengah dengan sasaran guru di tiga desa, yakni desa Abar-abir, Indrodelik, dan Pegundan telah berjalan dengan baik, aman, dan lancar. Sebab itu, kami mengucapkan ribuan terima kasih kepada

1. Ketua STKIP Qomaruddin Gresik;

2. Wakil Ketua III Bidang Kemahasiswaan;

3. Kepala Lembaga Penelitian dan Pengabdian kepada Masyarakat; serta

4. Semua guru sekolah tingkat dasar di Abar-Abir, Indrodelik, dan Pegundan.

\section{DAFTAR PUSTAKA}

Aqib, Z. (2008). Pemanfaatan Multimedia Pembelajaran di Sekolah. Jakarta: PT Raja Grafindo Persada.

Asyrofi, S. (2010). Pembelajaran Multimedia. Surabaya: Insan Cendekia.

Kusnandar, A. (2007). Panduan Pengembangan Multimedia Pembelajaran. Jakarta: Depdiknas. 
JPP IPTEK, Mei 2018, Vol. 2, No. 1

Halaman ini sengaja dikosongkan 